\title{
Characterization of reservoirs for water supply in Northeast Brazil using high resolution remote sensing
}

\section{Caracterização de reservatórios para abastecimento de água no Nordeste do Brasil com uso de sensoriamento remoto de alta resolução}

\author{
Vladimir Fonseca Nascimento ${ }^{1}$ and Alfredo Ribeiro Neto ${ }^{2}$ \\ ${ }^{1}$ Secretaria de Desenvolvimento Econômico, Recife, PE, Brazil \\ ${ }^{2}$ Universidade Federal de Pernambuco, Recife, PE, Brazil \\ E-mails: vladfn@hotmail.com (VFN), alfredoribeiro@ufpe.br (ARN)
}

Received: April 21, 2017 - Revised: June 28, 2017 - Accepted: July 25, 2017

\begin{abstract}
This paper reports the application of information acquired by aerial survey to characterize water supply reservoirs in the Pajeú River Basin (Pernambuco State/Brazil). The survey was carried out with digital cameras of high spatial resolution and laser relief profiling (LiDAR technology). Two areas were selected to apply the remote sensing products. Small reservoirs in the Quixaba Creek Basin were identified based on their topographic characteristics. Given that the small reservoirs are "depressions" in the terrain, they can be "filled", resulting in a new Digital Terrain Model (DTM). The difference between the filled DTM and the original DTM makes it possible to identify the reservoirs. A summary of the results is: 61 reservoirs were correctly detected; 18 reservoirs were not detected; 13 reservoirs were detected erroneously. In another application, the storage capacity of the reservoirs belonging to the hydrosystems of Pajeú River Basin was estimated. The storage in these reservoirs and maximum surface area were estimated using DTM and geoprocessing tools. From the total of 31 reservoirs evaluated, eight were completely empty at the time of the LiDAR data collection. The official registers reported 83.83 million $\mathrm{m}^{3}$ for the storage capacity of these eight reservoirs, whereas our applications estimated the value at 70.23 million $\mathrm{m}^{3}$. This difference is explained by the loss of volume in the reservoirs due to the process of sediment transport.
\end{abstract}

Keywords: LiDAR; Semiarid; Water resources; Storage capacity.

\section{RESUMO}

Este artigo apresenta a aplicação de produtos adquiridos por levantamento aéreo para caracterização de reservatórios de abastecimento de água na Bacia do Rio Pajeú (Pernambuco/Brasil). O levantamento foi feito com câmeras digitais de alta resolução espacial e perfilamento de relevo a laser (tecnologia LiDAR). Foram selecionadas duas áreas para aplicação dos produtos de sensoriamento remoto. Pequenos reservatórios na Bacia do Riacho Quixaba foram identificados com base em suas características topográficas. Considerando que os pequenos reservatórios são "depressões" no terreno, eles podem ser "preenchidos" resultando em um novo MDT. A diferença entre o MDT preenchido e o MDT original torna possível a identificação dos reservatórios. O resumo dos resultados é: 61 reservatórios foram corretamente detectados; 18 reservatórios não foram detectados; 13 reservatórios foram detectados erroneamente. Em outra aplicação, foi estimada a capacidade de armazenamento dos reservatórios pertencentes aos hidrossistemas da Bacia do Rio Pajeú. O armazenamento nos reservatórios e a área superficial máxima foram estimados utilizando o MDT e ferramentas de geoprocessamento. Do total de 31 reservatórios avaliados, 8 estavam completamente vazios durante o sobrevôo. Os registros oficiais totalizam 83,83 milhões de $\mathrm{m}^{3}$ para a capacidade de armazenamento dos oito reservatórios, enquanto este trabalho estimou o valor de 70,23 milhões de $\mathrm{m}^{3}$. Essa diferença pode ser explicada pela perda de volume nos reservatórios devido ao processo de transporte de sedimento.

Palavras-chave: LiDAR; Semiárido; Recursos hídricos; Capacidade de armazenamento. 


\section{INTRODUCTION}

Water supply in Northeast Brazil (NEB) relies on the reservoirs that regularize discharges. Storage capacity varies from small reservoirs used on private properties to large reservoirs used for urban supply (also called hydrosystems). In this research, the range of reservoir capacities is very wide. For this reason, it is important to define the classes and categories of storage adopted by the authors. These classes are: small (less than 1 million $\mathrm{m}^{3}$ ) (LIEBE; VAN DE GIESEN; ANDREINI, 2005; RODRIGUES et al., 2012), middle (1-3 million $\mathrm{m}^{3}$ ) and large (more than 3 million $\mathrm{m}^{3}$ ) (ICOLD, 2011). The small ones may also be divided into three categories according to Rodrigues et al. (2012) based on Liebe, Van de Giesen and Andreini (2005): Category 1, with surface areas between 1 and 3 ha; Category 2 between 3 and 10 ha; Category 3 between 10 and 50 ha.

The NEB is 1,558 million $\mathrm{km}^{2}$ large and has a total of 17,083 reservoirs with surface area greater than 5 ha (CARVALHO et al., 2009). According to the database from Reservoir Monitoring System (SAR is the acronym in Portuguese - ANA (2016)) of the Brazilian National Water Agency (ANA), the total capacity of the main reservoirs in NEB is 707.36 billion $\mathrm{m}^{3}$, which corresponds to 508 reservoirs. Of this total, 391 have a capacity higher than 3 million $\mathrm{m}^{3}$, which accounts for $99.98 \%$ of total capacity registered on the SAR. The other 115 reservoirs together account for only 162 million $\mathrm{m}^{3}$. This corresponds to the main reservoirs and does not take into account the very small reservoirs. Despite their small proportion in relation to total capacity, these small and medium reservoirs $\left(<3\right.$ million $\left.\mathrm{m}^{3}\right)$ have an important role in the water supply of small rural communities whose needs are not met by the large hydrosystems. The water retained in the small reservoirs enables local distribution (KROL et al., 2011).

In regions with high water vulnerability, such as in the Northeast semiarid lands, successful water resources management is vital for the population and the environment. Accurate and up to date information on water availability are elements necessary for satisfactory management. Two points are essential to achieve this goal: detection of water bodies and an estimate of reservoir storage capacity. Years after the construction of dams, the process of reservoir sedimentation reduces the storage capacity, making the updating of the geometry characterization necessary.

Different types of remote sensors have been used in the volumetric characterization of reservoirs with a range of dimensions. Some examples are the Shuttle Radar Topography Mission (SRTM) applied in the Three Gorges reservoir in China (WANG et al., 2005), optical sensors such as Landsat (COLLISCHONN; CLARKE, 2016; RAN; LU, 2012) and MODIS (GAO; BIRKET'T; LETTENMAIER, 2012; OVAKOGLOU et al., 2016). The spatiotemporal monitoring of surface water bodies is also possible using remote sensors as the applications in wetlands (TULBURE; BROICH, 2013), in large reservoirs around the globe (GAO; BIRKETT; LETTENMAIER, 2012), nearshore bathymetry (PACHECO et al., 2015) and near real-time monitoring in Africa (PEKEL, et al., 2014). In the case of optical sensors, the volume can be obtained by multiplication of the inundated surface area (estimated from the image) by the depth determined with limnimetric stations, radar altimetry or GPS. Other remote sensing techniques have been developed in recent years for reservoir bathymetric survey such as the use of
TanDEM-X Synthetic Aperture Radar (ZHANG et al., 2016) and ICESat laser altimetry profile data (ARSEN et al., 2014).

In 2012 started a multiyear drought that affected streamflow and water storage in reservoirs in NEB. This drought is considered to be the most severe in the last decades in NEB (MARENGO; TORRES; ALVES, 2016). Owing to the lack of precipitation, many reservoirs were depleted and, at the moment of the aerial survey, they were partially or completely empty, making it possible to characterize the terrain in these reservoirs.

This paper aims to present methods to support the quantification of the storage capacity of reservoirs in order to improve water resources management by using geoprocessing techniques with a digital terrain model (DTM) acquired by LiDAR technology (Light Detection and Ranging) and orthophotos. The use of DTMs acquired by aerial survey with a laser sensor has become common in hydrological studies, mainly in the physical characterization of river basins and drainage systems applied to Geographical Information Systems (CASTRO et al., 2015). The present study explores the potential of aerial survey high spatial resolution products (LiDAR and orthophoto) for the volumetric characterization of water supply reservoirs in Pernambuco State, Northeast Brazil. These methods can be used for:

Detection and estimate of storage capacity of small reservoirs;

Updating of the storage capacity of the reservoirs belonging to the urban supply hydrosystems and irrigation (they were completely empty during the aerial survey).

\section{MATERIAL AND METHODS}

\section{Study area}

Two areas were selected for application of the remote sensing products: the Pajeú River basin (PRB) and Quixaba Creek Basin (QCB). An application was used to estimate the storage capacity of the reservoirs that belong to the hydrosystems of the PRB. Another application was used to detect small reservoirs (açudes) along the Quixaba Creek Basin (QCB) in NEB. Figure 1 shows the location of PRB and QCB.

The PRB is the largest river basin in Pernambuco with a drainage area of $16,838.74 \mathrm{~km}^{2}$, which corresponds to $17.02 \%$ of the territory of the State. The Pajeú River is $355 \mathrm{~km}$ long from the headwaters to the outlet at Lake Itaparica in the São Francisco River. The PRB has a tropical semiarid climate with a total annual potential evapotranspiration of 2,500.0 mm (BRASIL, 2011), approximately three times the annual average precipitation.

The hydrosystems of PRB have 31 reservoirs with a total storage capacity of $567.51 \mathrm{hm}^{3}$ according to official registers. Among them, there are 13 reservoirs with capacity less than 3 million $\mathrm{m}^{3}$ totaling $17.12 \mathrm{hm}^{3}$.

The QCB drains an area of $226.67 \mathrm{~km}^{2}$ and the Quixaba River itself is $28 \mathrm{~km}$ long. Its outlet is located at the Barra do Juá reservoir. All the waterways in QCB are intermittent, i.e., there is interruption of the streamflow during the dry season. This is a typical Northeastern semiarid region with low water availability due to high rates of evapotranspiration, low precipitation and 

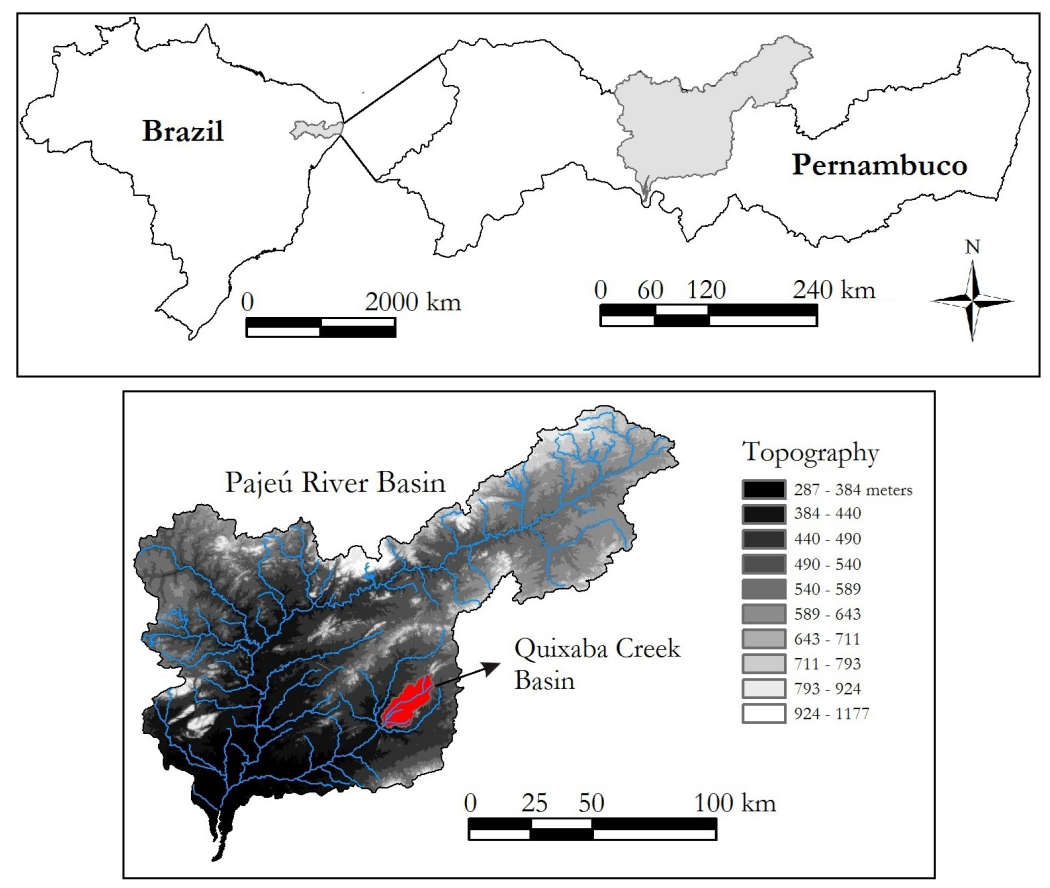

Figure 1. Study areas location.

shallow soil over crystalline rock. The main sources of water for dispersed human settlements are the small reservoirs spread along the basin.

\section{Project PE3D}

Three-Dimensional Pernambuco (PE3D) was a Pernambuco State Government project, aiming to map the entire territory of the State using aerial digital survey and laser relief profiling. The survey was carried out with eight airplanes equipped with high spatial resolution digital cameras (CIRILO et al., 2015). It was carried out during 2014 and 2016.

The LiDAR technique measures the travel time of the energy of a laser pulse between an airplane, the surface and back to the airplane. When the pulse reaches the surface, obstacles such as vegetation, water and constructions reflect the beams and a sensor on the airplane captures them. For every light beam emitted, the travel time and the angle of the scan mirror corresponding to the moment of the pulse emission are recorded. The association of these data with the altitude and the relative position of the airplane makes it possible to determine the three-dimensional coordinates of the surface targets (BLAIR; RABINE; HOFTON, 1999).

This digital aerophotogrammetric survey had a spatial resolution of $12 \mathrm{~cm}$ and the orthophoto with a scale of 1:1,000. The laser profiling had a maximum vertical error less than $10 \mathrm{~cm}$ and DTM generated over an extension of $870 \mathrm{~km}^{2}$ relative to the urban areas of 26 municipalities. For the remaining area of the State, the spatial resolution was $50 \mathrm{~cm}$ and orthophotos on the scale 1:5,000. The maximum vertical error was less than $25 \mathrm{~cm}$ and the DTM was generated for an extension of $98,146.0 \mathrm{~km}^{2}$. Figure 2 shows examples of products from the Project PE3D.
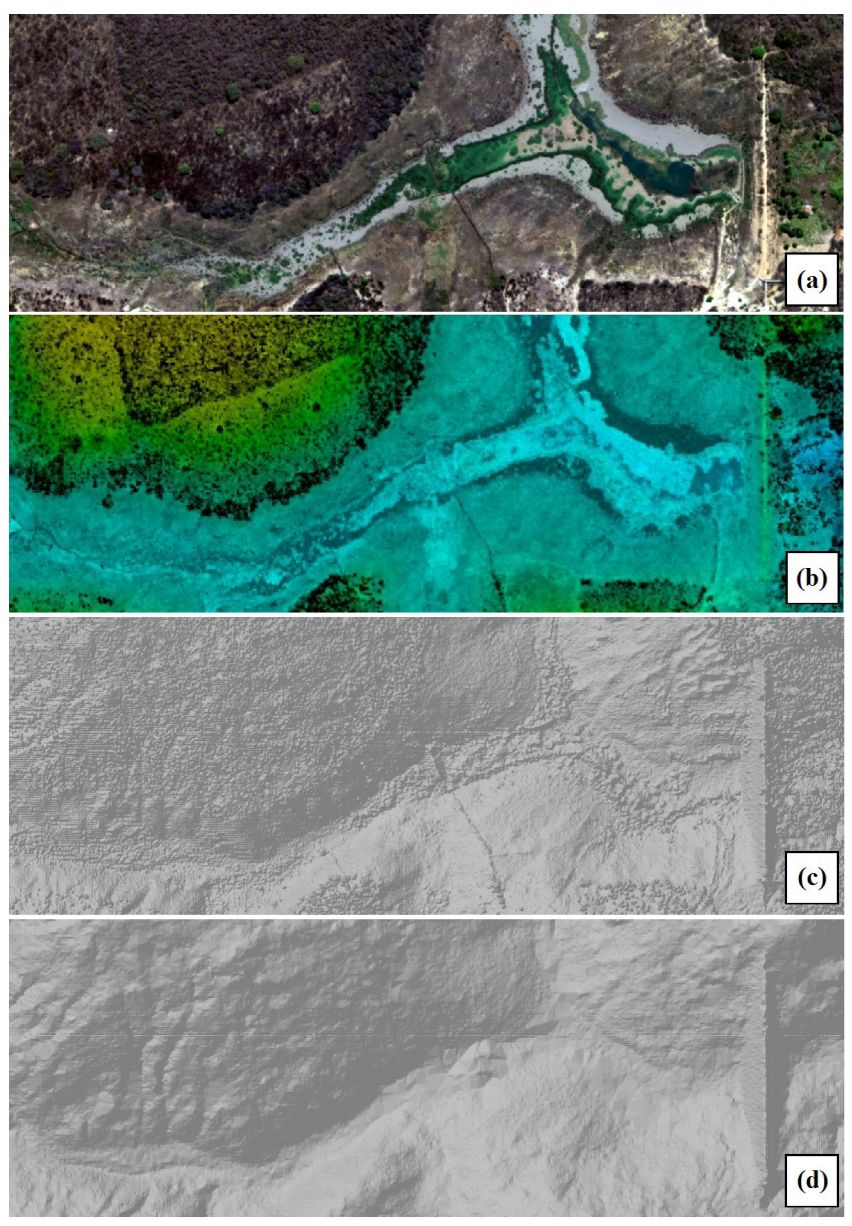

Figure 2. Examples of products from the PE3D mapping: (a) - Orthophoto; (b) - Image resulting from the composition of hypsometry and intensity of return of the light pulse; (c) - Digital Elevation Model; (d) - Digital Terrain Model. 


\section{Automatic detection of small reservoirs}

Small dams may be detected by their topographic characteristics. The application was carried out in the QCB using DTM and the composition of hypsometry and intensity (examples shown in Figures $2 \mathrm{~d}$ and $2 \mathrm{~b}$ respectively). The first step of the operation was to identify sinks in the DTM resulting from the LiDAR survey (hereafter referred to as DTM $_{\text {Lidar }}$ ). Sinks (also called depressions) are represented by pixels or groups of pixels indicating an elevation lower than the surrounding area. The depressions are corrected adding artificially elevation in order to define the flow direction of the water on the surface of the watershed. In this study, the processing used the algorithm D8 (deterministic eight-neighbors), where one of the eight flow directions was identified using the largest slope criteria (JENSON; DOMINGUE, 1988; MAIDMENT, 2002). However, there are regions of the DTM that contain depressions that hinder the flow routing. In Figure 3, for example, the center cell (highlighted in grey) is lowest than the eight neighbours. Using the algorithm D8, the depressions are raised to the lowest value on the border of the depression. This procedure ensures that the depressionless DTM is part of a decreasing path of cells leading to an edge of the region analysed (JENSON; DOMINGUE, 1988).

After the fill sinks operation, using map algebra, the original DTM $_{\text {Lidar }}$ was subtracted from the DTM ${ }_{\text {Lidar }}$ without depressions, resulting in a raster with a zero value for all pixels, except in the areas where before there was a depression. Figure 4 shows an example of a small reservoir with the original DTM $\mathrm{Lidar}_{\text {(a), the }}$

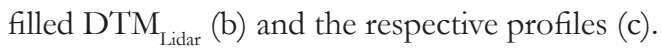

The result of the subtraction operation (DTM-subtraction) was to assign positive values to areas that could have natural depressions, surveying failure or small reservoirs in fact. In this case, only reservoir detection was of interest. The natural depressions and the failures of the $\mathrm{DTM}_{\text {Lidar }}$ were considered noise that had to be minimized. For this, the DTM-subtraction was reclassified using a threshold that defined the pixels representing the land and pixels representing small reservoirs. On the one hand, this classification reduced the amount of noise, but, on the other hand, shrank information about the extension of the reservoir's hydraulic basin (Figure 5). The hydraulic basin of a reservoir is the maximum surface area corresponding to its maximum level.

To overcome this difficulty, the reclassification of the DTM-subtraction was used just to locate the dams. Polygons were used to represent the reservoirs. A second layer was created with polygons representing the reservoirs obtained from the DTM-subtraction and threshold zero, i.e., without reclassification.

\begin{tabular}{|l|l|l|||l|l|l|}
\hline 44 & 36 & 25 & 44 & 36 & 25 \\
\hline 50 & 6 & 23 & 50 & 23 & 23 \\
\hline 53 & 41 & 36 & 53 & 41 & 36 \\
\hline
\end{tabular}

Figure 3. Elevation of a center cell and their eight neighbours as an example of simple fill sinks in the algorithm D8 (MAIDMENT, 2002).
The intersection between the two layers of polygons generated a vector with the small reservoirs detected, this time with the complete hydraulic basins.

The accuracy of the method was determined by comparing the results with the small reservoirs identified visually in QCB using orthophotos. A vector of points was created with three classes: the reservoirs identified, reservoirs not identified and noise. If a polygon (from the automatic detection) matched the point identified visually, the point was classified as detected. If the polygon appeared in a region of the orthophoto where dams did not exist, it was classified as noise (false positive). Finally, if there was no polygon at a location where a dam had been identified in the orthophoto, the point was classified as a non-detected reservoir (false negative). Table 1 shows the way of presentation of the results in a confusion matrix. The performance of the classification was evaluated by the overall accuracy of the identification, user's accuracy and producer's accuracy (Equations 1 to 3). The user's accuracy refers to a wrong assignment of the class and producer's accuracy means an excessive delimitation of the class. The more erroneous assignments, the lower the value of the user's accuracy. The greater the delimitation of the class, the lower the value of the producer's accuracy.

$$
\begin{aligned}
& A C=\left(\sum X_{i} / n\right) \cdot 100 \\
& A C_{u}=\left(\sum X_{i i} / X_{i+}\right) \cdot 100 \\
& A C_{p}=\left(\sum X_{i i} / X_{+i}\right) \cdot 100
\end{aligned}
$$

where:

$\mathrm{AC}$ is the overall accuracy

$\mathrm{ACu}$ is the user's accuracy

ACp is the producer's accuracy

$\mathrm{Xi}$ is the sum of the elements in the diagonal

Xii is the value of the diagonal of the line or column

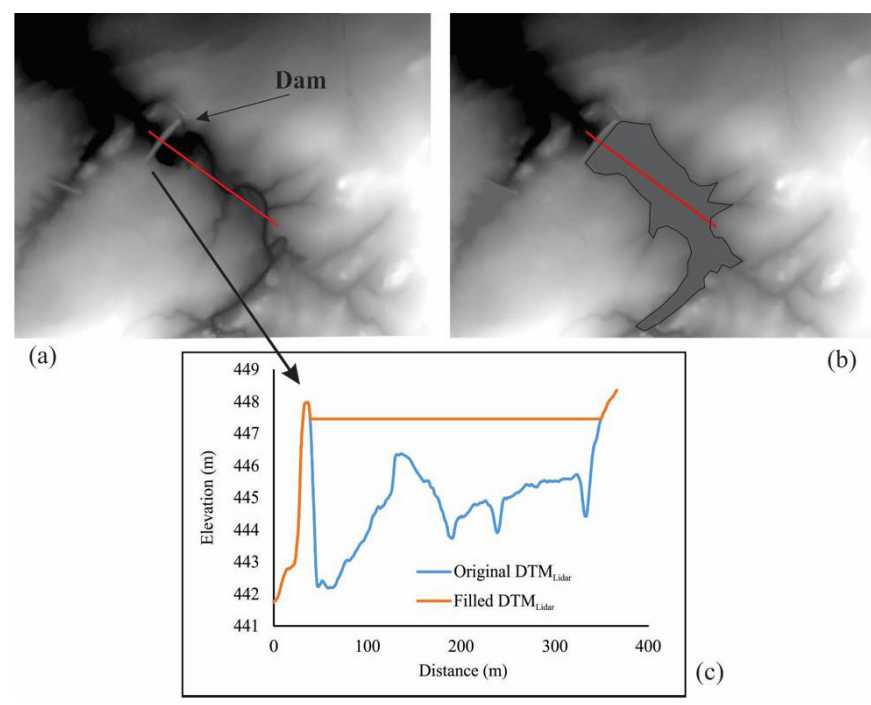

Figure 4. Reservoir with original DTM $\mathrm{Lidar}$ (a), filled DTM $\mathrm{Lidar}$ (b) and the respective profiles (c). 
$\mathrm{Xi}+$ is the total of elements of a class obtained from the classifications (line)

$\mathrm{X}+\mathrm{i}$ is the total of elements of a class obtained from the values of reference (column)

$\mathrm{n}$ is the total number of elements

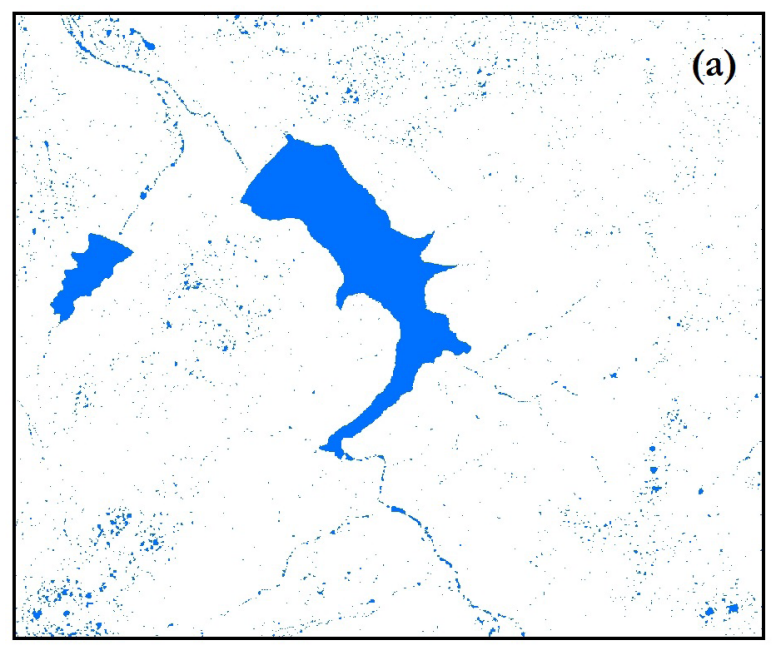

(b)
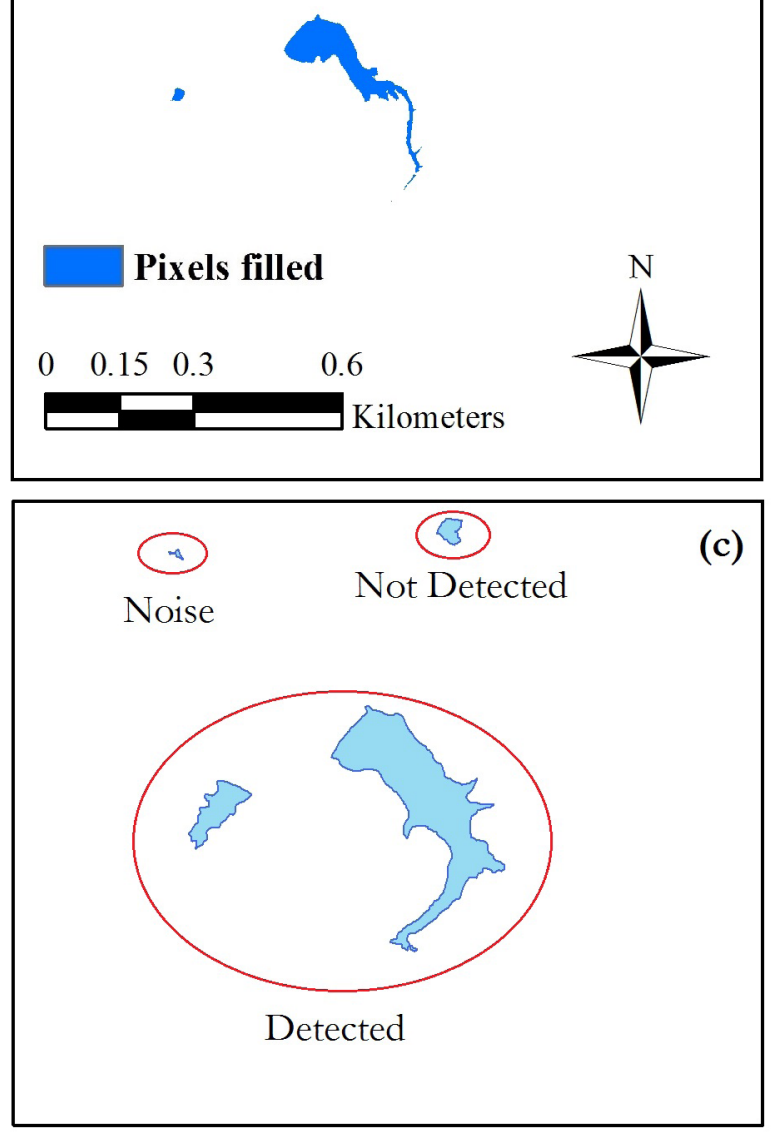

Figure 5. Result of the subtraction of the original DTM ${ }_{\text {Lidar }}$ from the filled DTM Lidar $_{\text {(a) }}$ (a) after the reclassification with application of threshold (b) and examples of reservoirs detected, not detected and noise (c).

\section{Estimate of storage capacity of reservoirs}

This part of the study was carried out in the reservoirs registered by the Water and Climate Pernambuco State Agency (APAC) in the Pajeu River Basin (Figure 6). APAC's database has 31 reservoirs registered in the $\mathrm{PRB}$, with a storage capacity ranging from $110,463.1 \mathrm{~m}^{3}$ to 59.5 million $\mathrm{m}^{3}$. The main uses are urban water supply and irrigation. They differ from the small reservoirs detected automatically in the Quixaba Creek, which are used for small farms in a rural zone.

The volume of the reservoirs was estimated using DTM Lidar $_{\text {}}$ and the Area and Volume tool (3D Analyst) of the ArcGIS Desktop 10.1. This tool calculates the volume and surface area below the plane that represents the water level. In addition to reservoir capacity, the elevation-area-volume curves are also determined, characterizing a bathymetric survey with remote sensing data.

\section{RESULTS AND DISCUSSION}

The results cover a broad range of reservoirs in terms of capacity and maximum surface area. This characteristic meets the needs of information for water management at different levels of complexity, from supply to dispersed human settlements to hydrosystems in urban areas.

Table 1. Structure of a confusion matrix.

\begin{tabular}{ccc}
\hline Class & $\begin{array}{c}\text { Positive Condition } \\
\text { of Reference }\end{array}$ & $\begin{array}{c}\text { Negative } \\
\text { Condition of } \\
\text { Reference }\end{array}$ \\
\hline $\begin{array}{c}\text { Positive } \\
\text { Classification } \\
\begin{array}{c}\text { Negative } \\
\text { Classification }\end{array}\end{array}$ & True Positive & False Negative \\
\hline
\end{tabular}

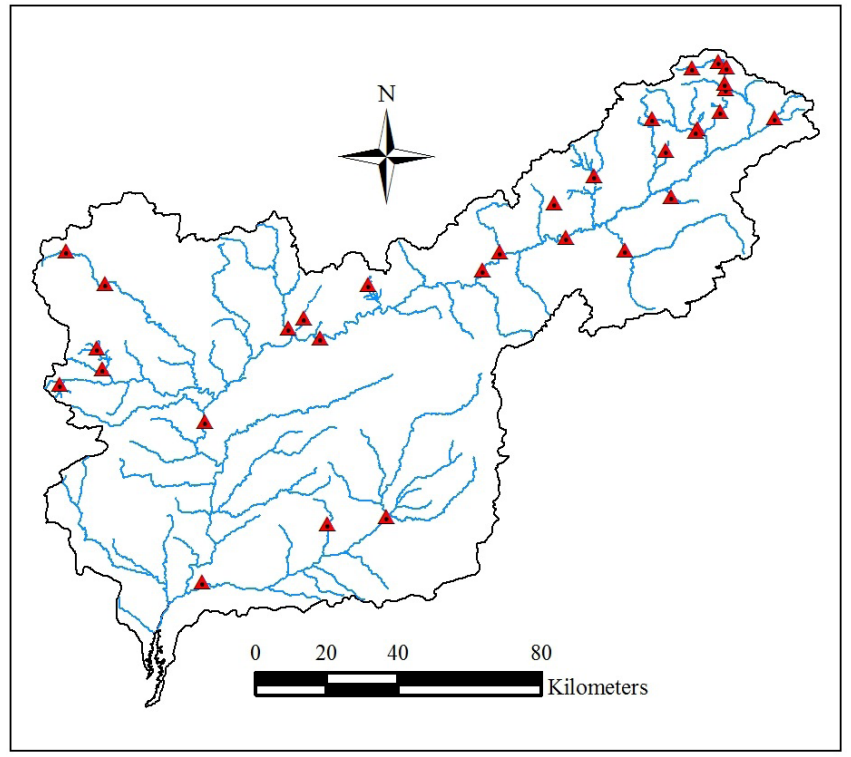

Figure 6. Location of the reservoirs in PRB. 


\section{Automatic detection of small reservoirs in the Quixaba Creek Basin}

Several tests were carried out in order to define the threshold by dividing the classes into pixels representing reservoir areas and pixels representing land. The value of the threshold was 2.24 meters (corresponding to $23.14 \%$ of the maximum depth filled in the original DTM Lidar $_{\text {I }}$, where the minimum depth was zero and the maximum was 9.69 meters. This means that all cells with a maximum depth filled lower than the threshold were not classified as reservoirs, removing the most of the noise in the study area and facilitating the identification of the reservoirs. In contrast, the maximum surface area did not keep to the dimensions established for the maximum water elevation; as well, very small reservoirs with a depth lower than the threshold (2.24 meters) were not identified. An example of result of the automatic detection using this threshold may be observed in Figure 5b.

The visual verification with orthophotos registered the following results:

- 61 reservoirs were correctly detected;

- 18 reservoirs were not detected;

- 13 sites were erroneously identified as reservoirs.

The area of the hydraulic basin of the detected reservoirs varied from 0.0281 ha to 9.43 ha and the storage capacity varied from $292.11 \mathrm{~m}^{3}$ to $81,791.27 \mathrm{~m}^{3}$, totalizing $526,109.11 \mathrm{~m}^{3}$. All the reservoirs may be considered as Categories 1 and 2 according to classification proposed by Liebe, Van de Giesen and Andreini (2005).

The confusion matrix for the results of automatic detection is presented in Table 2. The set of criteria described by Equations 1 to 3 calculated the overall accuracy $(66.30 \%)$, the producer's accuracy for the class "Reservoir" (77.22\%) and the user's accuracy (82.43\%) also for the class "Reservoir". These results show that $77.22 \%$ of the reservoirs in the study area were classified correctly (number of reservoirs correctly identified divided by the actual number of reservoirs). The results also show that $82.43 \%$ of all polygons created identified correctly the reservoirs (number of reservoirs correctly identified divided by the number of polygons assigned as reservoirs). The overall accuracy was $66.30 \%$, considering the reservoirs detected (True Positive), not detected (False Negative) and noise (False Positive).

In terms of storage capacity, the performance of the method was better than in terms of number of reservoirs. The Equations (1) to (3) can be applied using the reservoir capacities instead of the number of reservoirs. The overall accuracy was $87.86 \%$, the producer's accuracy for the class "Reservoir" was $89.87 \%$ and the user's accuracy was $97.52 \%$.

Table 3 shows the number of reservoirs detected and not detected per class of hydraulic basin surface area. The most reservoirs are concentrated between 0.01 and 2 ha (74 out of 79). Compared to the detection sensitivity of the Landsat images, the results obtained in QCB are considerably better. For example, Liebe, Van de Giesen and Andreini (2005) in the Upper East Region of Ghana classified 504 reservoirs, but had to disregard 348 with acreage less than 1 ha. In the QCB, 59 small reservoirs could be classified in Category 1 (less than $3 \mathrm{ha}$ ) according to classification mentioned before. Carvalho et al. (2009) used satellite CBERS-2 images to carry out a reservoir inventory for Brazilian territory. In the Northeast, 17,083 reservoirs with a surface area greater than 5 ha were identified. In the present study, 48 of the 61 reservoirs detected were smaller than 1 ha. Figure 7 shows the distribution of the maximum surface area in the QCB. Besides the sensitivity of detecting reservoirs smaller than 1 ha, the method presented here was also able to calculate the storage capacity, which is an advantage compared to previous studies that use satellite images.

\section{Storage capacities in reservoirs of Pajeu River Basin}

This part of the study deals with larger reservoirs used to supply the hydrosystems in the PRB. Characteristics of the reservoirs such as storage capacity, elevation-area-volume curves

Table 2. Confusion matrix of the reservoirs identification by using DTM $_{\text {Lidar }}$

\begin{tabular}{lccc}
\hline \multirow{2}{*}{ Class } & \multicolumn{2}{c}{ Reference } & \multirow{2}{*}{ Total } \\
\cline { 2 - 3 } & Reservoirs & Land* & \\
\hline Reservoirs & 61 & 13 & 74 \\
Land* & 18 & 0 & 18 \\
Total & 79 & 13 & 92 \\
\hline
\end{tabular}

*Pixels in areas outside the reservoirs.

Table 3. Number of reservoirs detected and not detected per class of hydraulic basin surface area.

\begin{tabular}{cccc}
\hline \multirow{2}{*}{$\begin{array}{c}\text { Hydraulic } \\
\text { basin area (ha) }\end{array}$} & \multicolumn{2}{c}{ Amount of reservoirs } & Total \\
\cline { 2 - 3 } & Detected & $\begin{array}{c}\text { Not } \\
\text { Detected }\end{array}$ & \\
\hline $0-1$ & 48 & 14 & 62 \\
$1-2$ & 10 & 2 & 12 \\
$2-3$ & 1 & 1 & 2 \\
$3-4$ & 0 & 1 & 1 \\
$4-5$ & 1 & 0 & 1 \\
$5-6$ & 0 & 0 & 0 \\
$6-7$ & 0 & 0 & 0 \\
$7-8$ & 0 & 0 & 0 \\
$8-9$ & 0 & 0 & 0 \\
$9-10$ & 1 & 0 & 1 \\
\hline
\end{tabular}

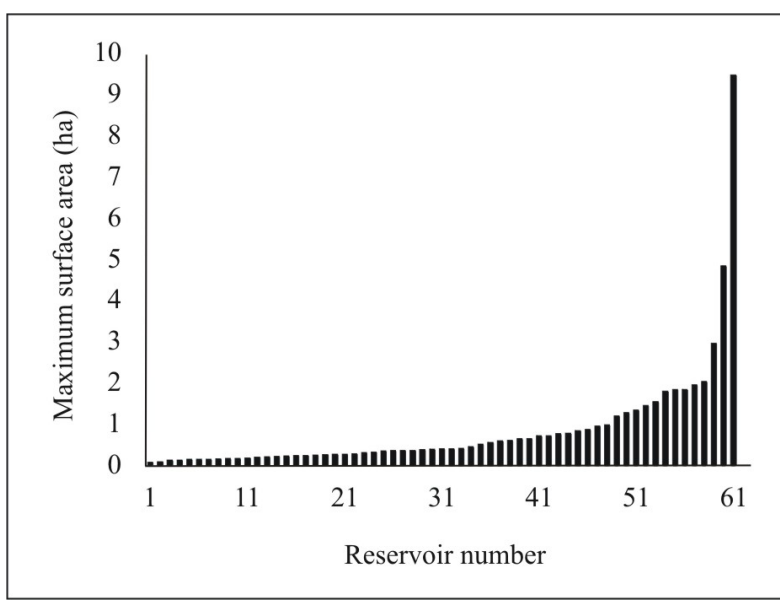

Figure 7. Maximum surface area of the reservoirs evaluated in the QCB. 
and year of construction are described in records of the Water and Climate Pernambuco State Agency (APAC). There is a mismatch between the altimetric references in the records and the DTM ${ }_{\text {Lidar }}$ information. The weir crest elevation was used as a reference point to match both datasets. A common reference point made it possible to establish the reservoir water elevation and depth at the moment of the aerial survey. The reservoir was considered empty when the volume of water was lower than $1 \%$ of the total storage capacity. From the total of 31 reservoirs evaluated, 8 were empty during the LiDAR data collection. The total storage volume of the 31 reservoirs was 567.51 million $\mathrm{m}^{3}$.

Table 4 shows the storage capacities estimated during the construction of the reservoirs; and using DTM ${ }_{\text {Lidar }}$, after the survey with LiDAR technology. Two of the eight reservoirs presented

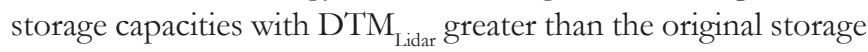
estimates. This means possible inconsistencies in the topographic database used at the moment of the construction of the reservoirs. The overall difference was $16.24 \%$ showing the discrepancy between the official registers and DTM ${ }_{\text {Lidar }}$.

\section{Improvement of storage capacity characterization with LiDAR technology}

The application of the method proposed to detect small reservoirs using the DTM ${ }_{\text {Lidar }}$ calculated satisfactorily the storage capacity of those reservoirs in the region of the Quixaba River. In general, this kind of information is not available to the institutions responsible for water management. The knowledge about the storage capacity from small reservoirs shows the spatial variability of the storage. This information can be useful to identify regions with greater water availability and support water planning in the basin.

Small reservoirs affect the process of runoff generation in a river basin. Detection and estimate of storage capacity are useful for the representation of small reservoirs in a rainfall-runoff model and for assessing the impact on the storage of middle and large reservoirs located downstream.

Considering the high spatial resolution $(50 \mathrm{~cm})$, it could be expected that the storage volume calculated with DTM $_{\text {Lidar }}$ would be more precise than the original surveys. In addition, over time, there would be a loss of volume in the reservoirs due to the process of sediment transport. This explains the differences observed between the capacities of the Table 4 .

Table 4. Storage capacity comparison.

\begin{tabular}{|c|c|c|c|}
\hline \multirow{2}{*}{ Reservoir } & \multicolumn{2}{|c|}{ Storage capacity $\left(10^{6} \mathrm{~m}^{3}\right)$} & \multirow{2}{*}{$\begin{array}{c}\text { Difference } \\
(\%)\end{array}$} \\
\hline & Original & DTM $_{\text {Lidar }}$ & \\
\hline Barra do Juá & 71.47 & 59.52 & -16.73 \\
\hline Chinelo & 3.45 & 2.93 & -15.06 \\
\hline Juá & 3.00 & 1.67 & -44.43 \\
\hline Boa Vista & 1.63 & 1.13 & -31.06 \\
\hline Mãe D’água & 1.50 & 1.34 & -10.56 \\
\hline Livino & 1.39 & 2.35 & 69.80 \\
\hline Laje do Gato & 1.10 & 0.99 & -10.01 \\
\hline Brejinho & 0.28 & 0.29 & 1.77 \\
\hline Total & 83.83 & 70.23 & -16.24 \\
\hline
\end{tabular}

An estimate of the precise storage capacity of the reservoirs is important for water resources management, especially, in semiarid regions like the Pajeú River Basin. The decisions made on the basis of overestimated storage capacities in a river basin may lead to erroneous strategies during periods of water scarcity.

Compared with other studies that use optical sensors, the application of a LiDAR survey is more precise because reservoir capacity is determined directly, i.e., the volume is calculated with geoprocessing tools. The methods that use optical sensors determine the volume indirectly, i.e., the image supplies the area of the water surface on different dates and the volume is calculated by multiplying the surface area by the differences in elevation. The determination of the bathymetry using LiDAR technology may be considered as reference for updating and comparison with future surveys. The accuracy of the aerial survey ensures that the curves stage-area-volume are precise for capacity comparison and estimate of sedimentation. The results obtained with LiDAR are also more precise than the traditional survey accomplished with eco-sounder directly in the reservoir. In addition, in many cases, the use of echo sounder must be complemented with topographic survey in order to characterize the reservoir entirely.

\section{CONCLUSIONS}

LiDAR technology was shown to be efficient for detection of small reservoirs in a small river basin in the Northeast of Brazil. The sensitivity to detect reservoirs with a hydraulic basin smaller than 1 ha was better than the application of images with a coarser resolution. The literature review accomplished did not find other studies or methods able to identify reservoirs with similar dimension. In addition, the other remote sensing methods do not generate a digital terrain model useful to retrieve the curves stage-area-volume as obtained in this work. The other application, the use of the DTM LiDAR in the determination of the storage capacity of middle and large reservoirs, had results good enough to encourage its use in other regions. The method shown in this paper can be considered more reliable and precise than the methods mentioned in the Introduction mainly due to the better resolution. Constant updating of the storage capacity is useful for decision makers in charge of the water resources management, especially during long drought periods. For example, the correct value of reservoir capacity is essential for simulation of hydrosystems using water allocation models. Despite the advantages highlighted, one limitation was observed in the use of LiDAR data, i.e., the reservoirs must be empty for its complete characterization.

The surface flow and the regime of discharges in the rivers are affected by the reservoirs located in the Northeast semiarid basins. The information about storage capacity can improve the quality of the results of rainfall-runoff models in basins with a large number of reservoirs. Another potential application is the assessment of reservoir sedimentation using the capacity estimated in the year of construction of the reservoir and the storage capacity updated with the DTM LiDAR. For partially empty reservoirs, equations must be built relating water surface to storage, using the values obtained in reservoirs completed empty at the moment of the aerial survey. 
Considering that the LiDAR survey covered the entire territory of the State of Pernambuco, it is now possible to apply the methods presented in this study for detection and updating of the storage capacity of the reservoirs in the remaining river basins of the state. In addition, the results obtained with the methods of automatic detection and updating of the storage capacity can be considered as reference for validation of other methods using coarser resolution optical sensors.

In other regions, in surveys using technologies such as LiDAR that generate DTM with high resolution and accuracy, future planning could take into account periods when the water level in reservoirs is low. In other words, the occurrence of the aerial survey during the dry season has two benefits: absence of clouds (good condition to acquire data) and low water level in the reservoirs.

\section{ACKNOWLEDGEMENTS}

This work was carried out with the aid of a grant from the Inter-American Institute for Global Change Research (IAI) CRN3056 which is supported by the US National Science Foundation (Grant GEO-1128040). The authors acknowledge the Pernambuco State Government for making the PE3D database available.

\section{REFERENCES}

ANA - AGÊNCIA NACIONAL DE ÁGUAS. Sistema de acompanhamento de reservatórios. 2016. Available from: <http:// sar.ana.gov.br/Nordeste>. Access on: 16 nov 2016.

ARSEN, A.; CRÉTAUX, J. F.; BERGE-NGUYEN, M.; DEL RIO, R. A. Remote sensing-derived bathymetry of Lake Poopó. Remote Sensing, v. 6, n. 1, p. 407-420, 2014. http://dx.doi.org/10.3390/ rs6010407.

BLAIR, J. B.; RABINE, D. L.; HOFTON, M. A. The Laser Vegetation Imaging Sensor: a medium-altitude, digitisation-only, airborne laser altimeter for mapping vegetation and topography. ISPRS Journal of Photogrammetry and Remote Sensing, v. 54, n. 2-3, p. 115-122, 1999. http://dx.doi.org/10.1016/S0924-2716(99)00002-7.

BRASIL. Ministério do Desenvolvimento Agrário. Plano Territorial de Desenvolvimento Rural Sustentável do Sertão do Pajeú. Brasília: Ministério do Desenvolvimento Agrário, 2011.

CARVALHO, M. S. B. S.; MARTINS, S. P. R. M.; SOARES, A. M. M.; CHAVES, L. C. G.; OLIVEIRA, F. A. J.; PERINI, D. S.; MENESCAL, R. A.; WARREN, M. S. Levantamento dos espelhos d'água acima de 20 ha em todo o território brasileiro através de sensoriamento remoto. In: BRAZILIAN SYMPOSIUM OF REMOTE SENSING, 14., 2009, Natal, RN, Anais... São José dos Campos: INPE, 2009. p. 1967-1974.

CASTRO, V. L. S.; LIMA, D. M.; COSTA, A. H. A.; PAZ, A. R. Processamento de modelo digital de elevação para estimativa do tempo de percurso do escoamento superficial. In: BRAZILIAN
SYMPOSIUM OF REMOTE SENSING, 17., 2015, João Pessoa, PB, Anais ... São José dos Campos: INPE, 2015. p. 6305-6312.

CIRILO, J. A.; ALVES, F. H. B.; SILVA, B. M.; CAMPOS, P. H. A. L. Pernambuco Tridimensional: Base de dados espaciais para planejamento urbano e gestão territorial. In: PORTUGUESESPEAKING COUNTRIES SYMPOSIUM OF HYDRAULICS AND WATER RESOURCES, 12., 2015, Brasília, DF, Anais... Porto Alegre: ABRH, 2015.

COLLISCHONN, B.; CLARKE, R. T. Estimativa e incerteza de curvas cota-volume por meio de sensoriamento remoto. Brazilian Journal of Water Resources, v. 21, n. 4, p. 719-727, 2016.

GAO, H.; BIRKETT, C.; LETTENMAIER, D. P. Global monitoring of large reservoir storage from satellite remote sensing. Water Resources Research, v. 48, n. 9, p. 1-12, 2012. http://dx.doi. org/10.1029/2012WR012063.

ICOLD - INTERNATIONAL COMMISSION ON LARGE DAMS. Constitution. Paris, 2012. 21 p.

JENSON, S. K.; DOMINGUE, J. O. Extracting topographic structure from digital elevation data for geographic information system analysis. Photogrammetric Engineering and Remote Sensing, v. 54, n. 11, p. 1593-1600, 1988.

KROL, M. S.; DE VRIES, M. J.; VAN OEL, P. R.; ARAÚJO, J. C. Sustainability of small reservoirs and large scale water availability under current conditions and climate change. Water Resources Management, v. 25, n. 12, p. 3017-3026, 2011. http:// dx.doi.org/10.1007/s11269-011-9787-0.

LIEBE, J.; VAN DE GIESEN, N.; ANDREINI, M. Estimation of small reservoir storage capacities in a semi-arid environment: a case study in the Upper East Region of Ghana. Physics and Chemistry of the Earth, v. 30, n. 6, p. 448-454, 2005. http://dx.doi. org/10.1016/j.pce.2005.06.011.

MAIDMENT, D. R. Arc Hydro: GIS for water resources. Redlands: ESRI, 2002.

MARENGO, J. A.; TORRES, R. R.; ALVES, L. M. Drought in Northeast Brazil-past, present, and future. Theoretical and Applied Climatology, v. 129, n. 3-4, p. 1189-1200, 2016. http://dx.doi. org/10.1007/s00704-016-1840-8.

OVAKOGLOU, G.; ALEXANDRIDIS, T. K.; CRISMAN, T. L.; SKOULIKARIS, C.; VERGOS, G. S. Use of MODIS satellite images for detailed lake morphometry: Application to basins with large water level fluctuations. International Journal of Applied Earth Observation and Geoinformation, v. 51, p. 37-46, 2016. http://dx.doi. org/10.1016/j.jag.2016.04.007.

PACHECO, A.; HORTA, J.; LOUREIRO, C.; FERREIRA, O. Retrieval of nearshore bathymetry from Landsat 8 images: a tool for coastal monitoring in shallow waters. Remote Sensing of 
Environment, v. 159, p. 102-116, 2015. http://dx.doi.org/10.1016/j. rse.2014.12.004.

PEKEL, J.-F.; VANCUTSEM, C.; BASTIN, L.; CLERICI, M.; VANBOGAERT, E.; BARTHOLOMÉ, E.; DEFOURNY, P. A. Near real-time water surface detection method based on HSV transformation of MODIS multi-spectral time series data. Remote Sensing of Environment, v. 140, p. 704-716, 2014. http://dx.doi. org/10.1016/j.rse.2013.10.008.

RAN, L.; LU, X. X. Delineation of reservoirs using remote sensing and their storage estimate: An example of the Yellow River basin, China. Hydrological Processes, v. 26, n. 8, p. 1215-1229, 2012. http:/ / dx.doi.org/10.1002/hyp.8224.

RODRIGUES, L. N.; SANO, E. E.; STEENHUIS, T. S.; PASSO, D. P. Estimation of small reservoir storage capacities with remote sensing in the Brazilian Savannah region. Water Resources Management, v. 26, n. 4, p. 873-882, 2012. http://dx.doi.org/10.1007/s11269011-9941-8.

TULBURE, M. G.; BROICH, M. Spatiotemporal dynamic of surface water bodies using Landsat time-series data from 1999 to
2011. ISPRS Journal of Photogrammetry and Remote Sensing, v. 79, p. 44-52, 2013. http://dx.doi.org/10.1016/j.isprsjprs.2013.01.010.

WANG, Y.; LIAO, M.; SUN, G.; GONG, J. Analysis of the water volume, length, total area and inundated area of the Three Gorges Reservoir, China using the SRTM DEM data. International Journal of Remote Sensing, v. 26, n. 18, p. 4001-4012, 2005. http://dx.doi. org/10.1080/01431160500176788.

ZHANG, S.; FOERSTER, S.; MEDEIROS, P.; ARAÚJO, J. C.; MOTAGH, M.; WASKE, B. Bathymetric survey of water reservoirs in north-eastern Brazil based on TanDEM-X satellite data. The Science of the Total Environment, v. 571, p. 575-593, 2016. PMid:27418521. http://dx.doi.org/10.1016/j.scitotenv.2016.07.024.

\section{Authors contributions}

Vladimir Fonseca Nascimento: results obtained from the DTM, literature review, text writing.

Alfredo Ribeiro Neto: paper conception, revision of the results obtained from the DTM, literature review, text writing. 